\title{
A STUDY ON THE MEDICAL AND SOCIOLOGICAL FACTORS EXERTING INFLUENCE UPON LEPROSY PATIENTS DISCHA- RGED FROM LEPROSARIUM
}

_ Tentative Plan of Forecast Methods for Rehabilitation of Patients

\author{
Shigenobu KOBAYASHI and Yuzuru MATSUMURA \\ National Leprosarium, Kuryu-Rakusen-en
}

\begin{abstract}
The healed patients discharged from leprosaria are increasing graduall in Japan by the remarkable developement of antileprosy drugs in this country, where leprosy patients have been isolated in leprosaria by the law. The number of discharged patients at present, however, is not sufficient because about one half of all patients in leprosaria are bacilli-negative; for example about $70 \%$ of patients iu National Leprosarium, Kuryu-Rakusen-en. are bacilli-negarive.

Why the percentage of discharged cases in all patients is low at precent in spite of the remarkable incsease of the bacillinegative patients? This question is for the management of leprosaria in future. As a result, nine factors which influenced upon the rehabilitation of leprosy patients were obtained, and a kind of the tetative plan of forecast methods were made for rehabilitation. This plan will be investigated in other leprosaria for the practical use.
\end{abstract}

\section{らい患者の社会復帰に影響を与光る医学的 社会的要因の研究}

付 社会復帰予测法試案

$$
\text { 小林茂信* ・松村 譲* }
$$

\section{緒言}

戦後における治りい薬の進歩に著しい木のがあり，

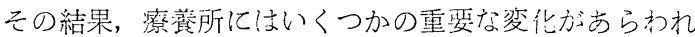
た。その一つは與菌者の増加であり，他!治退園者の 出現である。

前者は本園における35年度の調盗によってもL瑟艎者 中の56\%を占め，T型患者を加えると，全入園患者の然 に70灾が無菌患者であるという結喿である。また治浔退 園者屯 34 年度 8 名，35年度14名，さらに36年度において

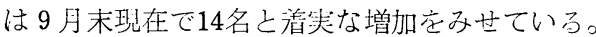

終生隔離をたてまえとした，本邦らい政笠，それにす とずく潦養所体制の中にあって，たとえ僅加であるにも

* 小林茂信 栗生楽泉園

* 松村 讓

（1961年10月25日受稿）
せよ退園者が出はじわた事は曙光でもあるが，7割にも およぶ無菌者（隔離収容老必要とせ女者）の存在という 療羡所の現状は，1〜2\%台の退所率では上うてい满足 する事を許さぬもので尚る。

しかし現实には，患者の療養への定着化定企脳した明 治以米の終年隔離策によって，患者の生活体制は，これ に順忍するものよなり，らい医学の進歩による潦粯所の 軽換に即忍山来ず，社会復帰者数は依然低い段階に止志 っている。

患者の外出を制限し，所内での生活在規制するらい尒 防法, 䝤羡規則は，それが排菌者に対応する限りに志い て合目的であり得るが，これが無菌者，治ゆ患者に対応 する時人権拜視の誹を免れえ存在となる。したがって 無菌者, 治ゆ患者の多数出現した今日, これらの社会復 州を助成, 促進する事はらい回復者の人権を考慮す万上 
加ら屯重要な亨で市万う。この社会復帰促進の途上に横 たわる障害は，社会学的にも，医学的にあ種々考えられ るであろうが, むっ上も重要な問題は患者個人個人の社 公復帰意欲の向上で苟る。

したがって本研究においては終生隔離をたてまえとし たらい療養所にける社会復帰意欲状態の把挃。社会復帰 阳害因子の確認定通じて, 社会復帰の促進を図る上での 資料を得万事在目的亡し，併せて調查加ら得られた資料 在もとにして社会復帰予测表の作成志試みた。乙れは The Gluecks ${ }^{122}$ ) の犯罪予測理諭の応用であるが，乙れ によって患者の社会後帰を予測する事が出来ると共に, 将来における漅養所運営に資する隶が出来机ば幸であ る。

\section{調查方法}

1）乙の調查は全数調査, 配票自計式方法利用した 統計調査であり, 年令, 結婚病型, 身体障害程度の独立 項目は調査者において記入した。

2) 調査項目

(1)年令(2)結㚜(3)性別(4)病型(5)らい菌(6)療養年数(7)实体 障害程度等級 (視力, 上肢, 下肢, 聴力平衡機能, 体幹 それぞれの程度等級) (8)社会生活経験(療用生活の中断) の有無(9)家族との交通の有無(10家族之の面会の有與，立 園外に居る家族の質, 过本人の退所に対する家族の態度 (本人の予想), 祊社会復帰希望の有無, 而社会復帰㫜害 因子, 迆社会復帰の時期, 更社会復㷌の前提条件, 国就 職希望の有無, (18)希望職種。以上が調查項目の全である が, (11)15:16の項目はPretestの段階に現方えた图子を採 用し選択肢を用意した。

3）調査票の配布之回收

調查票の配布総数は精神病棟入室中の三名を除いた 982票で，これを36・7・29日世話人を通じて配布し， 7

・31 不在その他で記入末了の調査票もすべて回双し た。結果は回収総数 980 票。回収不能 2 票であり, 980 票 の回収票中, 記入もれ, 誤記等集計不能のもの65票を除 外して,915の有効調查票を得た。有効回收率は93.10で 当る。

\section{主要成績と所見}

本調査の性格上, 分析は社会復帰希望者, 悲希望者之 つ相異に主たるポイントを置いて分析した。

1）年令, 性別之社会復帰希望

第 1 図より，退園希望者は男 40 才，女 30 才を境として 急激に減退する事实が知られる。また 61 才以上で再で復 帰希望者百分率の上昇がみられるが，これは年令と就識
第 1 図 年令・性别上社会復帰希望

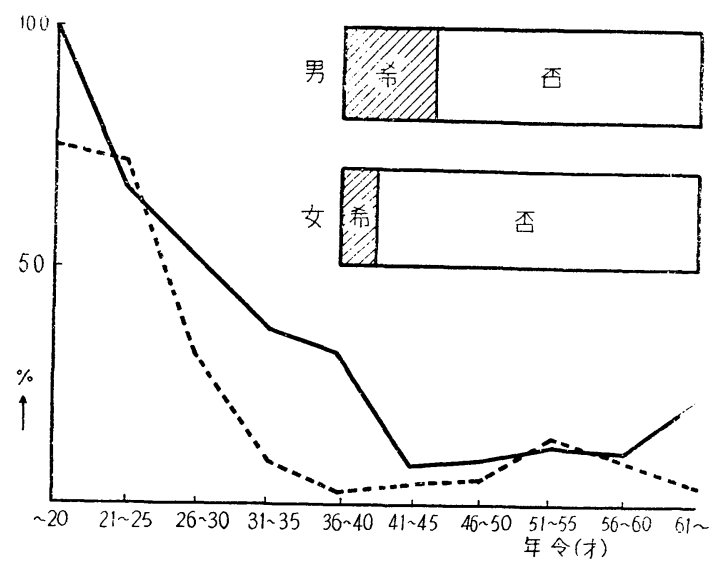

希望の項（第10図）でむ明らかな如く，自立の必要なき あのの増加による。性別による社会復帰希望は, 男20.4

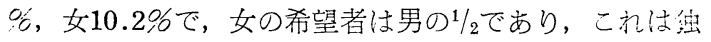
身，既婚をとわず一般にるられる现象である。

2）療養年数之社会復㴆希望

籍 2 図㮦求年数之退所希望

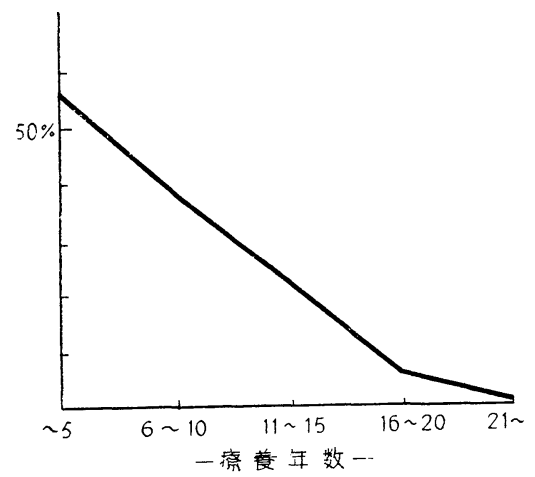

第 2 図にみる如く, 在園年数にほぼ反比例して退所希 望者が減退する。らいの治療は退園希望の多い 5 年以内 に全治させ得るよう努力せ㸚ばなら好。しかし当園に尔 ける無菌化と治療年数との関係は， L型患者については 第 3 図の如くで， 5 年前後 $34 \%, 8$ 年前後で $48 \%$ 之理想 には程遠しの感がある。なほ現入園者の平均在園期閒は 16.3 年である。

\section{3）所内結婚と社会復帰希望}

所内における結婚が，社会復帰阻害因子となるであろ う柬は予想された事であるが，調査からも復帰希望者の 64.6\%が独身者であり，既暜者の $91.1 \%$ が社会復帰を希 望せぬ者である事が知られた。したがって終生隔離を目 的としたらい療養所では, 結婚こそ患者を園内に止めて おく最良の方法であったが，琴在のように社会復帰苦考 
第3 図 L型患者における治療期間別らい菌陰性率 $<35$ 年度調 $>$

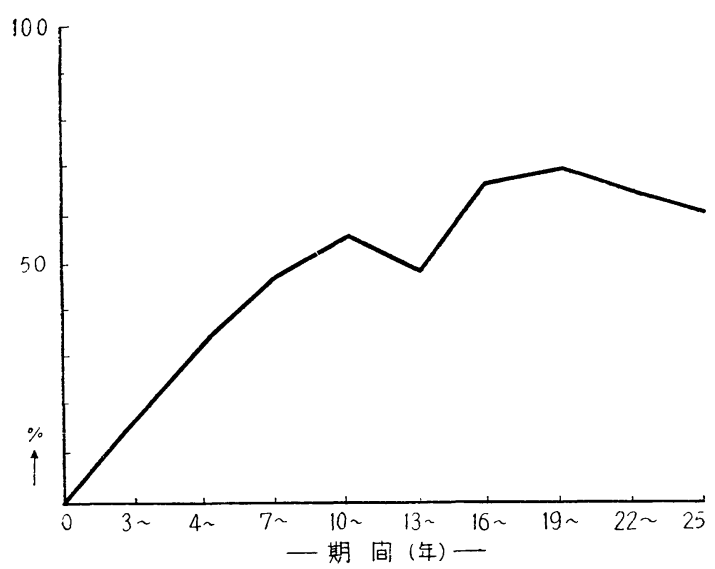

第 4 図 所内結婚と社会復帰

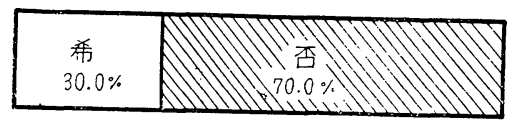

独身者

と社会復帰

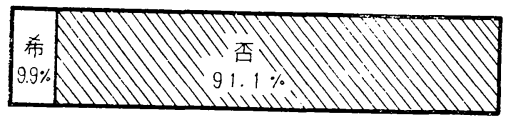

既婚者

と社会復帰

独身者 $64.6 \%$

既婚吉

$35.4 \%$

復帰希望者

と結㛭

慮する時期になると，乙れは当然に阻害要因として働く ようになるので, 治ゆ退園可能のものが所内結婚する事 については充分説得がなされてしかるべきである。

4）社会生活経験之社会復帰希望

社会生活経験者＝退所経験者が本病再発者であり，社 会生活の敗北者であるとの観点からは，退所未経験者と の対比において，復帰希望の相対的減弱が予想されたの であるが，結果は以下の如くで経験者には復帰希望者が 多く，乙の点からは無菌者を所外で㗢かせることによ り，社会を知らせ，それを通じて社会復帰意欲の助長を 図る露もとるべき一方法であろうと思われる。

第 5 図 社会生活経験と社会復帰

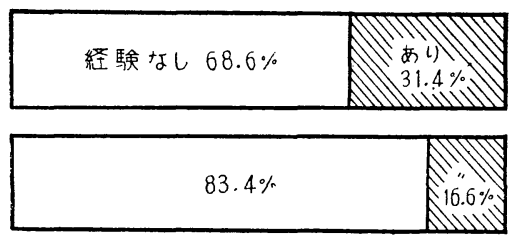
希 望 者 非希望者

\section{5）家族との結びつきと社会復帰希望}

この項目では指標として家族との文通，面会を最近一 カ年を区切っって採用した。結果は以下の如くで，復帰 希望者の $85.3 \%$ が便りを通じて， $58.8 \%$ が面会を通じて 家族との結びつきを保っている。

第 6 図 文通と社会復帰

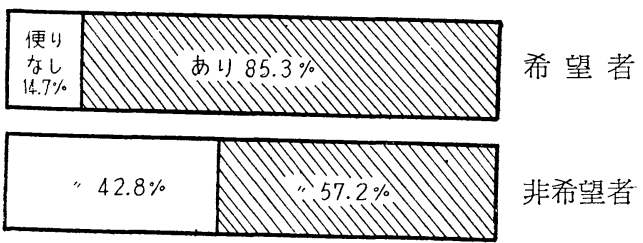

第 7 図 面会と社会復帰

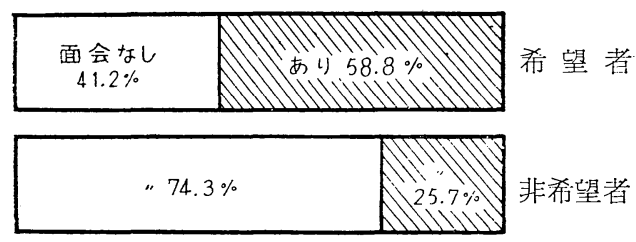

本人の退所に対する家族の態度と復帰侨望との関連を みたのが第 8 図である。

第 8 図家族の態度と社会復帰

家族はかん

げいする

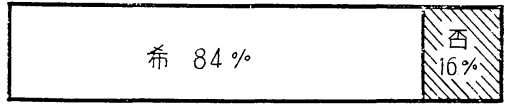

いやがる

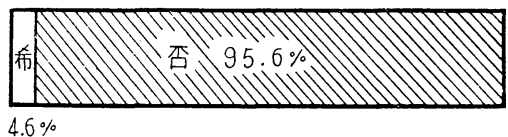

6）社会後帰の時期

本項の調査は一つには具体的サービスを用意する上で の実態把握を目的としたものであったが，副次的に社会 復帰希望の具体性判定に用いられる。

第 9 図 社復帰の時期

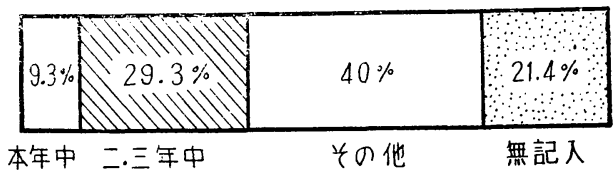

7）社会復帰の前提条件

社会復帰の意欲の持ちながらも，いざ退所となるとそ こに又あらためて種々の障害があらわれるであろう事が 
十分想像出来る。本項は，その障害あるいは要望とも云 うべきむのを吸いあげる目的で設定した。

選択肢は®本病が治ったら®技術を覚えたら(C)自分に 適した仕事がみつかったらゆ支度金が出来たら@整形手 術が成功したら@本病以外の病気が治ったら@配偶者之 離別出来たら、である。

結果は第 1 表の如くで，全数調査である事加らの当然 の結果ではあろうが，社会的要望と云うより，むしろ医 学的要望と云う面が強くあらわれている。また記入方法

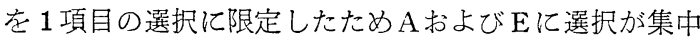
したが，記入方法によっては異なる結果が得られたであ 万う。

第 1 表 所内結婚と社会復帰

\begin{tabular}{|c|c|c|c|c|c|c|c|c|c|c|}
\hline & & $\mathrm{A}$ & B & $\mathrm{C}$ & D & $\mathrm{E}$ & $\mathrm{F}$ & $\mathrm{G}$ & 無 & 計 \\
\hline \multirow{3}{*}{ 男 } & 独 身 & 45 & 2 & 4 & 6 & 13 & - & - & 12 & 28 \\
\hline & 既 婚 & 16 & 2 & 4 & 1 & 4 & - & 1 & 3 & 31 \\
\hline & 計 & 61 & 4 & 8 & 7 & 17 & - & 1 & 15 & 113 \\
\hline \multirow{3}{*}{ 女 } & 独 身 & 7 & - & - & 1 & - & - & - & 7 & 15 \\
\hline & 既 婚 & 12 & - & 2 & 1 & 1 & - & - & 6 & 22 \\
\hline & 計 & 19 & - & 2 & 2 & 1 & - & - & 13 & 37 \\
\hline & 総 計 & 80 & 4 & 10 & 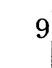 & 18 & - & 1 & 28 & 150 \\
\hline & 百分率 & .3 & 2.0 & 6.6 & 6.0 & 12.0 & & 0.6 & 8.9 & 100 \\
\hline
\end{tabular}

8）社会復帰之就職希望

第 2 表 性, 所内結婚之就職希望

\begin{tabular}{|c|c|c|c|c|c|c|c|}
\hline & 独身男 & 尧婚男 & 計 & 独身女 & 㭠婚女 & 計 & 総計 \\
\hline $\begin{array}{ll}\text { 就 職 } \\
\text { 严 }\end{array}$ & 43 & 23 & 66 & 3 & 14 & 17 & 83 \\
\hline $\begin{array}{l}\text { 就な職 } \\
\text { しない }\end{array}$ & 39 & 8 & 47 & 12 & 8 & 20 & 67 \\
\hline 計 & 82 & 31 & 113 & 15 & 22 & 37 & 150 \\
\hline 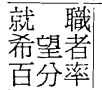 & 52.4 & 74.1 & 63.2 & 20.0 & 63.6 & 41.8 & 55.3 \\
\hline & A & B & $\frac{A+B}{2}$ & $\mathrm{~A}^{\prime \prime}$ & $\mathrm{B}^{\prime \prime}$ & $\frac{\mathrm{A}^{\prime \prime}+\mathrm{B}^{\prime \prime}}{2}$ & \\
\hline
\end{tabular}

40才を境之して就職希望者の急激な減退がみられる。 これは中, 高年者層の就職自立が困難であると予想され ることから，中，高年者層の復帰希望は，すで就職自 立の必要と云う網の目をくぐり抜けて来た者によって多 数を占められているてとを示している。

9）退所阻害因子
第10図 年令と就職希望

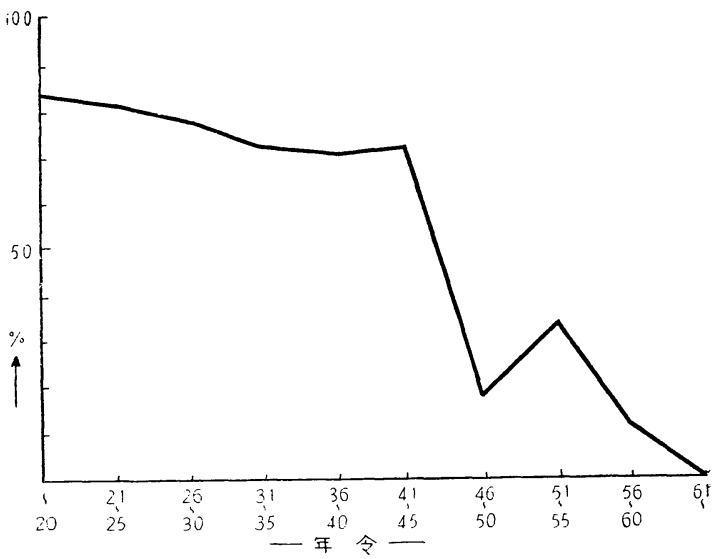

本調查において退所を希望しなかった者765人に対し， 本人が退所出来嫄因とするものを以下の $\mathrm{A} \sim \mathrm{N}$ までの 14項目より， 3 項目を限定して選択させた所第 3 表の結 果を得た。選択肢 (A)社会の偏見が恐万しい(B社会で役 に立つ技術がない@社会で働いても生活が楽になるとは 思えない(D)自分に適する仕事がないと思う身体が不自 由で働けない(巨本病が治っていない@配偶者の病状が悪 く独りでは出たくない円その他(配偶者が不自由者なの で退所しても生活が出来吅㗢くには年をとりすぎたし 老後の生活が不安®病弱で社会人之一緒には働けない( 再発が恐万しい@後遺症があるので働くのが心配®住居 や支度金がないので退所出来妨。

第 3 表 性別, 所内結婚之障害因子

\begin{tabular}{|c|c|c|c|c|c|c|c|c|c|}
\hline & 独身 & 既妭 & 計 & 而率 & 独身 & 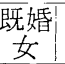 & 計 & 百分 & 男女計 \\
\hline A & 53 & 86 & 139 & 11.7 & 17 & 80 & & 11.1 & 236 \\
\hline B & 17 & 21. & 38 & 3.1 & 3 & 12 & & 1.7 & 53 \\
\hline $\mathrm{C}$ & 6 & 19 & 25 & 2.1 & 4 & 12 & 16 & 1.8 & 41 \\
\hline D & $19 !$ & 34 & 53 & 4.4 & 7 & 31 & 38 & 4.3 & 91 \\
\hline $\mathrm{E}$ & 140 & 175 & 315 & 26.4 & 31 & 193 & $224 \%$ & 25.7 & 539 \\
\hline $\mathrm{F}$ & 68 & 121 & 189 & 15.8 & 16 & 129 & 145 & 16.7 & 334 \\
\hline G & 1 & 17 & 18 & 1.5 & - & 19 & 19 & 2.1 & 37 \\
\hline $\mathrm{H}$ & - & - & - & - & - & 1 & 1 & 0.2 & 1 \\
\hline I & 8 & 26 & 34 & 2.9 & 4 & 16 & 20 & 2.4 & 54 \\
\hline $\mathrm{J}$ & 31 & 69 & 100 & 8.3 & 19 & 56 & 75 & 8.7 & 175 \\
\hline $\mathrm{K}$ & 44 & 33 & 77 & 6.5 & 16 & 53 & 69 & 7.9 & 146 \\
\hline L & 8 & 29 & 37 & 73.1 & 5 & 25 & 30 & 3.5 & 67 \\
\hline M & 44 & 83 & 127 & 710.6 & 8 & 78 & 96 & 9.8 & 213 \\
\hline $\mathrm{N}$ & 15 & 27 & 42 & 23.6 & 4 & 31 & 35 & 4.1 & 77 \\
\hline 計 & 454 & 740 & 1,194 & $\begin{array}{l}4 \\
100\end{array}$ & 134 & 736 & 870 & 100 & 2,064 \\
\hline
\end{tabular}


男女们に阻害因子の差異はみられず，阻害因子順位の 高位を占めるものは医学的因子が多い。※対象者 765 人 中, 無記入77名, したがって得点合計は $688 \times 3=2,064$ となる，なお円項は調査者において各項に投入した。

10）総合身体障害程度と社会復帰希望

らい患者の身体障害は，上肢とか下肢に限局して認め ら机るむのでなく，視力，上肢，下肢に合併して認めら れる上に知覚麻㿁在伴う。したがって，その中むっとも 障害の程度の高い級, 或は合併による上位の級で示され る等級が身障程度をかならずしむ正しく評価していると は思われないが，ここでは一応とれを用いた。これによ ると身障程度が軽くなるほど復帰希望者は增加する。第 3 表の Eが高率であるととと共に四肢の変形が, 社会復 㴆の大きな阻害因子となる事が知られる。この事から理 学療法, 整形手術術式の改良は勿論必要であるが，早期 発見，早期治療により後遺症なく治功さす事が最む重要 であると云える。

第11図 総合障害程度と社会復帰希望

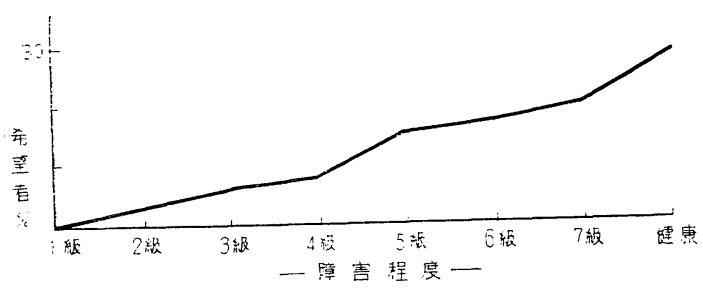

11）上肢障害程度上社会復帰希望 上肢障害程度之社会復帰希望は関係する。

第12図上肢障害程度上社会復帰希望

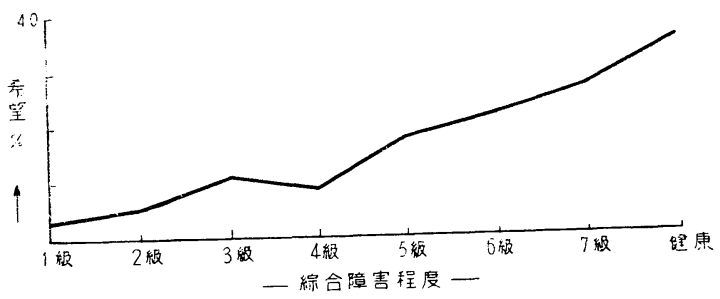

12）下肢障害程度と社会復帰希望

13） N症状上社会復帰希望

らい研究協議会の病状判定基隼の $\mathrm{n}$ 病状之社会復㴆希 望との関係は, 神経症状の軽いn日 L , T両型聞の社会復帰希望者割合に優劣はない。

\section{社会復帰予測表試案}

長期の療養生活，それも終生隔離策が基本策として，
第13 図 下肢障害程度と社会復帰希望

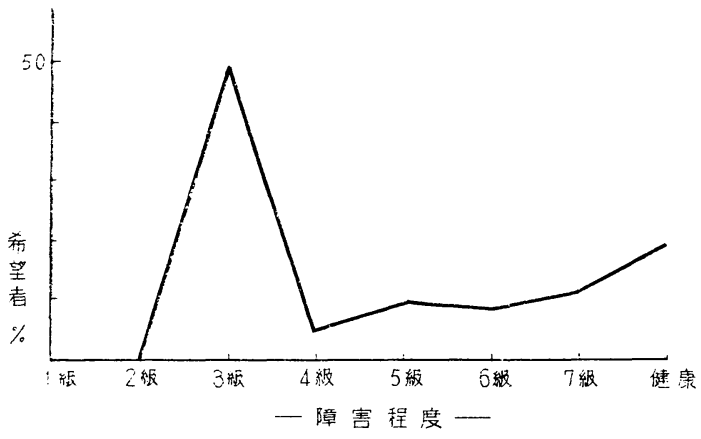

籍 4 表 $n$ 症状と社会復帰希望

\begin{tabular}{|c|c|c|c|c|c|c|}
\hline \multicolumn{3}{|c|}{ 社会復帰の意志 $\mathrm{n}$ 症状 } & $\mathrm{n} 1$ & $\mathrm{n} 2$ & n3 & 計 \\
\hline \multirow{3}{*}{$\mathrm{L}$ 型 } & 有 & $\begin{array}{c}\text { 実 数 } \\
\%\end{array}$ & $\begin{array}{l}54 \\
30.6\end{array}$ & $\begin{array}{l}37 \\
18.9 \\
\end{array}$ & $\begin{array}{c}19 \\
5.9 \\
\end{array}$ & $\begin{array}{r}110 \\
15.9 \\
\end{array}$ \\
\hline & 無 & $\begin{array}{c}\text { 実 数 } \\
\%\end{array}$ & $\begin{array}{r}122 \\
69.4\end{array}$ & $\begin{array}{r}158 \\
81.1 \\
\end{array}$ & $\begin{array}{c}300 \\
94.1 \\
\end{array}$ & $\begin{array}{r}580 \\
84.1 \\
\end{array}$ \\
\hline & 計 & $\begin{array}{c}\text { 実 数 } \\
\%\end{array}$ & $\begin{array}{l}176 \\
100 \\
\end{array}$ & $\begin{array}{l}195 \\
100 \\
\end{array}$ & $\begin{array}{l}319 \\
100 \\
\end{array}$ & $\begin{array}{l}690 \\
100 \\
\end{array}$ \\
\hline \multirow{3}{*}{ T型 } & 有 & $\begin{array}{c}\text { 実 数 } \\
\%\end{array}$ & $\begin{array}{l}18 \\
28.5\end{array}$ & $\begin{array}{l}10 \\
19.6 \\
\end{array}$ & $\begin{array}{l}10 \\
10.6 \\
\end{array}$ & $\begin{array}{l}38 \\
18.2 \\
\end{array}$ \\
\hline & 無 & $\begin{array}{l}\text { 実 数 } \\
\%\end{array}$ & $\begin{array}{l}45 \\
71.5\end{array}$ & $\begin{array}{l}41 \\
80.4\end{array}$ & $\begin{array}{l}84 \\
89.4\end{array}$ & $\begin{array}{r}170 \\
81.8 \\
\end{array}$ \\
\hline & 計 & 実 数 & $\begin{array}{r}63 \\
100 \\
\end{array}$ & $\begin{array}{r}51 \\
100 \\
\end{array}$ & $\begin{array}{r}94 \\
100 \\
\end{array}$ & $\begin{array}{l}208 \\
100\end{array}$ \\
\hline
\end{tabular}

第14网 $\mathrm{n}$ 症状亡社会復帰希望

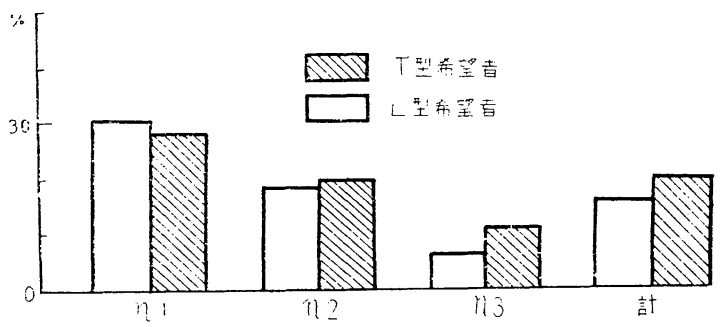

つい昨日までその命脈を保っており, 本邦らい療養所に あっては, 社会復帰なる言葉, その勧奖は患者の生活態 勢に 180 度の転換を迫るものである。回復退所者の出現 と云う事実が，警異の目を持って迎えられるのは，それ が過去との対比に置かれての事であって, $1 \sim 2 \%$ 退 所率は，70\%台の無菌者と云う現実の要求するすのから ははるかに隔たったものでしかない。

ここに採り上げた社会復帰予测表は，この現実を前に して, (1)復帰可能者状態の把握, およびこれを対象とし 
ての退所锥奖の尺度として。(2)患者の社会復帰に附随す る就職その他の具体的サービスを用意する上での数量把 握。(3)退所可能者でありながら社会復帰を希望せ女者に 対するフォローアップによる対策の樹立と云うつの目的 を有している。

1）テストの方法

社会復帰に対する態度調査によって社会復帰希望を表 明した者の調査票中，記入の完全なる者 135 を選び，そ 㣗に対応するコントロール・グループとして, 社会学的 因子の検定には医学的条件の。医学的因子の検定には社 会学的条件のそ机ぞれ等しいむの135を社会復帰を希望

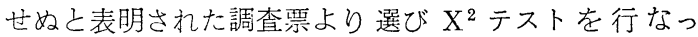
た。以下はその結果であり, 復帰希望, 非希望両グルー プの問で99\%以上の安全度をむって有意差ありと云い切 机る因子 9 個を得て，乙机を社会復帰予測因子として採 用した。

成績 1 年令と社会復帰

\begin{tabular}{|c|c|c|c|c|c|c|c|c|c|c|}
\hline \multirow[t]{2}{*}{ 年 } & \multirow[t]{2}{*}{ 令 } & \multicolumn{3}{|c|}{ 希望する } & \multicolumn{3}{|c|}{ 苻望しない } & \multicolumn{3}{|c|}{ 計 } \\
\hline & & 実 & & 百分率 & 実 & 数 & 百分率 & & 数 & 分率 \\
\hline & 30 & & 36 & 74 & & 13 & 26 & & 49 & 100 \\
\hline 31 & 40 & & 47 & 49 & & 49 & 51 & & 96 & 100 \\
\hline 41 & & & 52 & 42 & & 73 & 58 & & 125 & 100 \\
\hline & & & 135 & & & 135 & & & 270 & \\
\hline
\end{tabular}

成績 2 社会生活経験と社会復帰

\begin{tabular}{|c|c|c|c|c|c|c|c|c|c|c|}
\hline \multirow{2}{*}{\multicolumn{2}{|c|}{ 社会生活経験 }} & \multicolumn{3}{|c|}{ 希望する } & \multicolumn{3}{|c|}{ 希望しない } & \multicolumn{3}{|c|}{ 計 } \\
\hline & & & \multicolumn{2}{|c|}{ 数 百分率 } & \multicolumn{3}{|c|}{ 帣 数百分率 } & \multicolumn{3}{|c|}{ 数百分率 } \\
\hline あ & り & & 66 & 76 & & 21 & 24 & & 87 & 100 \\
\hline な & L & & 69 & 38 & & 114 & 62 & & 183 & 100 \\
\hline \multicolumn{2}{|c|}{ 計 } & & 135 & & & 135 & & & 270 & \\
\hline
\end{tabular}

成績 3 所内結婚と社会復帰

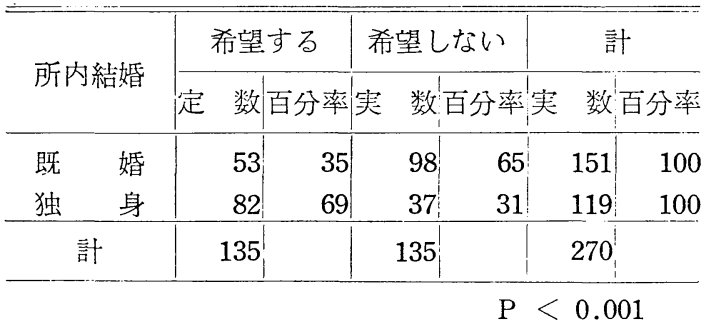

成績 4 療養年数亡社会復帰

\begin{tabular}{|c|c|c|c|c|c|c|c|c|c|c|}
\hline \multirow{2}{*}{ 年 } & \multirow{2}{*}{ 数 } & \multicolumn{3}{|c|}{ 希望する } & \multicolumn{3}{|c|}{ 希望しない } & & \multicolumn{2}{|c|}{ 計 } \\
\hline & & 実 & 数 & & 实 & 数 & 分率 & 実 & & 分率 \\
\hline & 5 & & 23 & 77 & & 7 & 23 & & 30 & 100 \\
\hline 6 & 15 & & 82 & 63 & & 49 & 37 & & 131 & 100 \\
\hline 16 & & & 30 & 28 & & 79 & 72 & & 109 & 100 \\
\hline & & & 135 & & & 135 & & & 270 & \\
\hline
\end{tabular}

成績 5 家族の態度と社会復帰

\begin{tabular}{|c|c|c|c|c|c|c|c|c|}
\hline \multirow{2}{*}{ 家茶の態度 } & \multicolumn{3}{|c|}{ 希望する } & \multicolumn{3}{|c|}{ 希望しない } & \multicolumn{2}{|c|}{ 訊 } \\
\hline & 实 & 粠? & 率 & 実 & 数 & 率来 & 数 & 分率 \\
\hline かんげいする & & 53 & 95 & & 3 & 5 & 61 & 100 \\
\hline $\begin{array}{l}\text { いちがいにい } \\
\text { えぬ }\end{array}$ & & 23 & 46 & & 27 & 54 & 50 & 100 \\
\hline いやがる & & 14 & 18 & & 65 & 82 & 79 & 100 \\
\hline 計 & & 95 & & & 95 & & 190 & \\
\hline
\end{tabular}

成績 6 家族との結びつきと社会復帰

\begin{tabular}{|c|c|c|c|c|c|c|c|c|c|}
\hline \multirow{2}{*}{ 文 } & \multirow{2}{*}{ 通 } & \multicolumn{2}{|c|}{ 希望する } & \multicolumn{3}{|c|}{ 希望しない } & \multicolumn{3}{|c|}{ 計 } \\
\hline & & 実 数百 & 率 & & 数 & 百分率: & 实 & 数 & 分率 \\
\hline あ & り & 116 & 58 & & 85 & 42 & & 01 & 100 \\
\hline な & L & 19 & 29 & & 50 & 71 & & 69 & 100 \\
\hline & & 135 & & & 135 & & & 70 & \\
\hline
\end{tabular}

成績 7 垂手垂足と社会復帰

\begin{tabular}{|c|c|c|c|c|c|c|c|c|}
\hline & \multicolumn{3}{|c|}{ 希望する } & \multicolumn{3}{|c|}{ 希望しない } & \multicolumn{2}{|c|}{ 計 } \\
\hline & 実 & & 百分率 & 実 & 数 & 百分率 & 实 数 & 百分率 \\
\hline $\mathrm{D}_{0}$ & & 94 & 56 & & 75 & 44 & 169 & 100 \\
\hline $\mathrm{D}_{1}$ & & 15 & 43 & & 20 & 57 & 35 & 100 \\
\hline $\mathrm{D}_{2}$ & & 5 & 28 & & 13 & 72 & 18 & 100 \\
\hline $\mathrm{D}_{3}$ & & 1 & 13 & & 7 & 87 & 8 & 100 \\
\hline 計 & & 115 & & & 115 & & 230 & \\
\hline
\end{tabular}


成績 8 手指屈曲障害と社会復帰

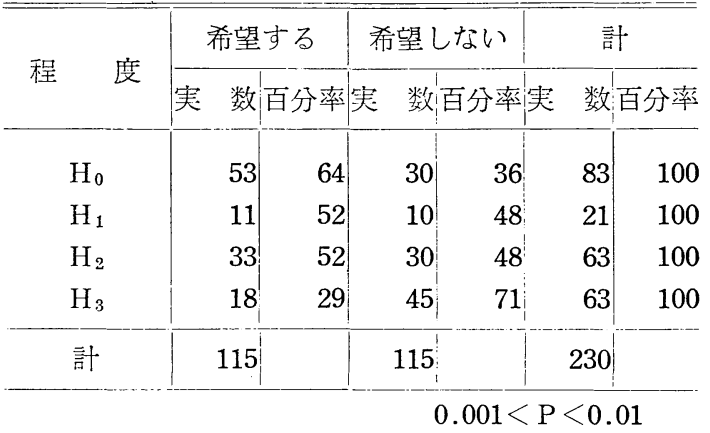

成績 9 視力障害之社会復帰

\begin{tabular}{|c|c|c|c|c|c|c|c|c|}
\hline & \multicolumn{3}{|c|}{ 希望する } & \multicolumn{3}{|c|}{ 希望しない } & \multicolumn{2}{|c|}{ 計 } \\
\hline & 䨍 & 数百 & 百分率 & 害 & 数 & 百分率実 & & 分率 \\
\hline 1 & & 4 & 16 & & 21 & 84 & 25 & 100 \\
\hline 2 & & 5 & 42 & & 7 & 58 & 12 & 100 \\
\hline 3 & & 3 & 43 & & 4 & 57 & 7 & 100 \\
\hline 4 & & 1 & 33 & & 2 & 67 & 3 & 100 \\
\hline 5 & & - & - & & 3 & 100 & 3 & 100 \\
\hline 6 & & 2 & 33 & & 4 & 67 & 6 & 100 \\
\hline 0 & & 120 & 65 & & 94 & 35 & 214 & 100 \\
\hline 計 & & 115 & & & 115 & & 230 & \\
\hline
\end{tabular}

成績 10 顔面麻㽻と社会復帰

\begin{tabular}{|c|c|c|c|c|c|c|}
\hline & \multicolumn{2}{|c|}{ 希望する } & \multicolumn{2}{|c|}{ 希望しない } & \multicolumn{2}{|c|}{ 計 } \\
\hline & 実 数 & 文百分率 & 実 数 & 分率 & 実 数 & 百分率 \\
\hline $\mathrm{F}_{0}$ & 73 & 58 & 52 & 42 & 125 & 100 \\
\hline $\mathrm{F}_{1}$ & 12 & 45 & 15 & 55 & 27 & 100 \\
\hline $\mathrm{F}_{2}$ & 13 & 46 & 15 & 54 & 28 & 100 \\
\hline $\mathrm{F}_{3}$ & 17 & 34 & 33 & 66 & 50 & 100 \\
\hline 計 & 115 & & 115 & & 230 & \\
\hline
\end{tabular}

成績11 $\mathrm{n}$ 症状と社会復帰

\begin{tabular}{|c|c|c|c|c|c|c|c|c|}
\hline & \multicolumn{2}{|c|}{ 希望する } & \multicolumn{3}{|c|}{ 希望しない } & \multicolumn{3}{|c|}{ 計 } \\
\hline & 実 数 & 百分率 & 実 & 数 & 予率 & & 数 & 分率 \\
\hline $\mathrm{n} 1$ & 52 & 60 & & 35 & 40 & & 87 & 100 \\
\hline $\mathrm{n} 2$ & 29 & 50 & & 29 & 50 & & 58 & 100 \\
\hline n3 & 34 & 40 & & 51 & 60 & & 85 & 100 \\
\hline 計 & 115 & & & $115^{\mid}$ & & & 30 & \\
\hline
\end{tabular}

成績12 面会亡社会復帰

\begin{tabular}{|c|c|c|c|c|c|c|c|c|}
\hline \multirow{2}{*}{ 面 } & \multirow{2}{*}{ 会 } & \multicolumn{2}{|c|}{ 希望する } & \multicolumn{3}{|c|}{ 希望しない } & \multicolumn{2}{|c|}{ 計 } \\
\hline & & 実 数 & 百分率 & 実 & 数 & 分率实 & 数 & 百分率 \\
\hline な & し & 78 & 46 & & 91 & 54 & 169 & 100 \\
\hline 苛 & り & 57 & 56 & & 44 & 44 & 101 & 100 \\
\hline & & 135 & & & 135 & & 270 & \\
\hline
\end{tabular}

採朋老み西わせた 3 因子は上記(1)顔面麻瘨 (2) $\mathrm{n}$ 症状 (3)面会である。

2) 各因子の数量化

社会的，医学的因子にもとずいて社会復帰予测表をつ くるために，まず各因子の社会復帰に対する関連性の度 合を数量化することが必要で，この少法として加重得失 点方式を採用した。その方法は，各因子の小別け項目に 刘応する社会復帰希望者の頻度を示古百分率を，それぞ れの得失点とするあので，9因子の小別け項目に対して 与えられる得失点を計算すると以下の表が得られる。

成績 13

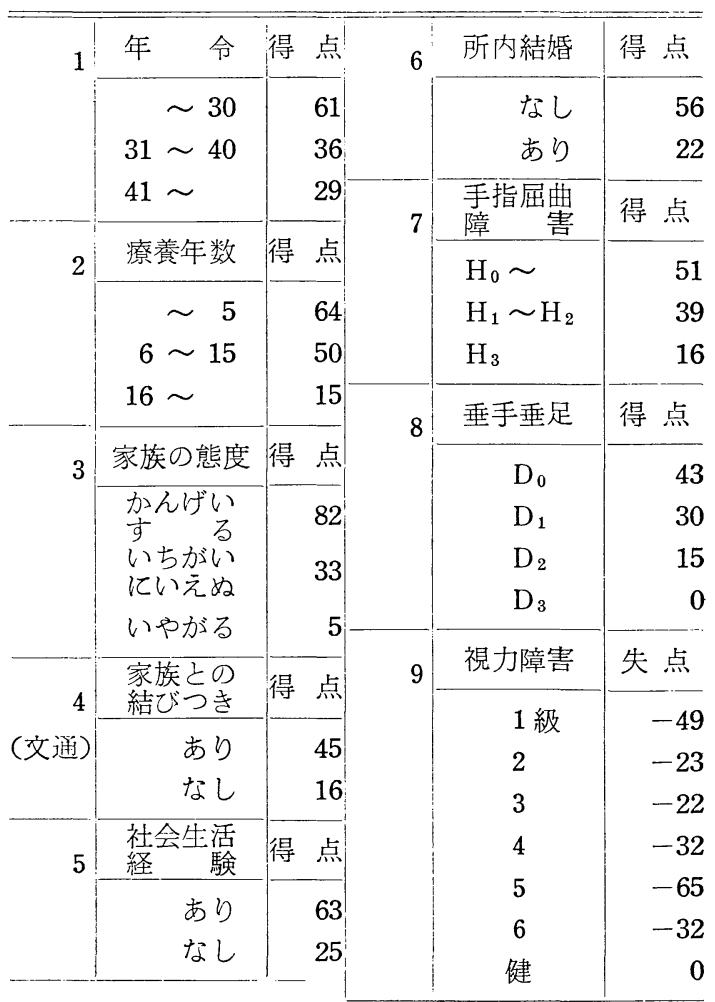

成績 13：得点は 得点を○に読み換え他の項目より 13を減じ。失点は障害なしの失点を○に読み変え他に35 
を加えた。

次に各調査表についての合計得点を計算した。これら の合計得点の分布は, 最低可能得点 63 加 ら, 最高可能得 点443にわたり, 合計得点の分布を得点の級別之社会復 帰希望の有無之の相関表にすると以下となる。

成績 14

\begin{tabular}{|c|c|c|c|c|}
\hline 得＼cjkstart点 & $\begin{array}{l}\text { 希望する } \\
\text { 者の数 }\end{array}$ & 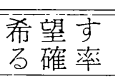 & $\begin{array}{l}\text { 希望しな } \\
\text { (者の数 }\end{array}$ & $\begin{array}{l}\text { 希望しな育 } \\
\text { 心確 率 }\end{array}$ \\
\hline$\sim 150$ & - & - & 11 & 100 \\
\hline $151 \sim 199$ & 3 & 8 & 33 & 92 \\
\hline$z 00 \sim 249$ & 16 & 25 & 49 & 75 \\
\hline $250 \sim 299$ & 17 & 36 & 30 & 64 \\
\hline $300 \sim 349$ & 42 & 76 & 13 & 24 \\
\hline $350 \sim 399$ & 40 & 93 & 3 & 7 \\
\hline $400 \sim$ & 21 & 100 & - & - \\
\hline 計 & 139 & & 139 & \\
\hline
\end{tabular}

成績 14：ての相関表をグラフにしてみると以下の図 が得られる。 320 点を境亡して, それ以下なら社会復帰 を希望する確率が著しく低く，それ以上だと復帰を希望 する確率が急に高くなる。320 点を境として社会復帰希 望の有無を予測する事によって起る誤差は希望する者に ついては約 $26 \%$, 希望しない者については $12 \%$, 平均 19 96で逆に云えば 100 名中 81 名までは, この予测表を使っ て社会復帰希望の有無を識別出来る事を示している。

成績 15

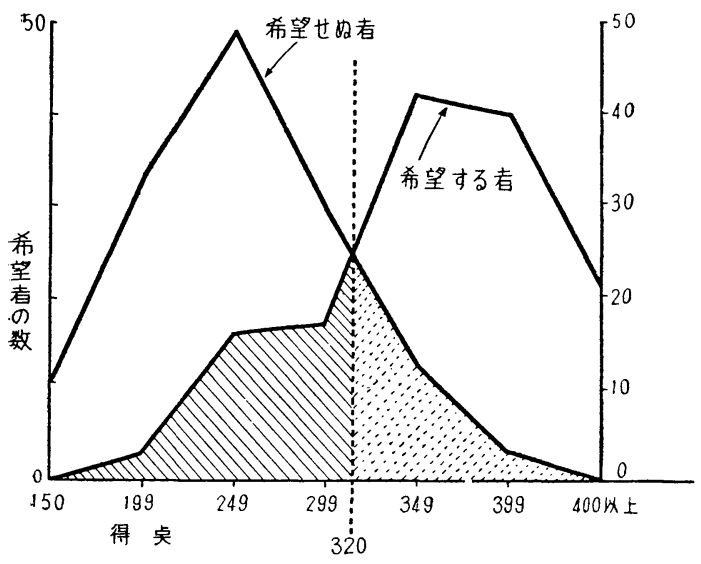

考按

以上が当療養所における社会復帰予測表の作製過程, およびその結果であるが， Glueck の犯罪予測表の作製 過程と対比して，ここでは各因子の数量化の基礎に患者 の社会復帰希望の有無と云う主観的事実を使用したこ上 が特徴的である。これは客観的事実としての社会復帰者 の絶対数の不足，および過去における統計的資料の不足 から，やむをえずとられた方法であるが，乙れがこの予 測表の信頼度を引下げている事は否めない。しかしまた 患者群を 2 大別したポイントが, 社会復帰希望の有無に 置かれた事から, 各因子の評価值は, 患者の意志を反映 したものとなっており，退所基準の設定という面から は, 医学的因子のみの客観的評価値以上に説得力西方 のとなっている。

本調査において採用した13個の予測因子は，先にも蜟 れた如く，20数件のCase Study にあらわ机たあのから とりあげたものではあるが, 私達もこれで満足している わけではなく, 特に, より秀れた予測因子の発見, 或は 数量化の方法など, 諸賢の御批判, 追試をあおげればと 思っている。

\section{結語}

我々は, 栗生楽泉園入所中のらい患者の社会復帰に影 響を与える医学的, 社会的要因の統計的調査を行い, つ いで社会復帰予測表の試案を作製した。

\section{文献}

1) Glueck, Unrareling Juvenile Delinquency(1950)

2）安倍治夫：グリュック犯罪予測法入門 (1959)

3）らい研究協議会：らいの病状, 病勢及び病型の分類 とその記載要領 （1957） 